\title{
What Is the Maximum Worth of a Dairy Heifer?1
}

\section{Albert de Vries and Russ Giesy ${ }^{2}$}

Many Florida dairy farms purchase dairy heifers to replace their culled cows. The purchase price of a dairy heifer has varied the last several years from less than $\$ 1,000$ to more than $\$ 2,000$ per head. The major factors that determine the purchase price are the quality of the heifer and demand and supply. When heifer prices are higher than usual, many dairy producers question if they should purchase heifers now or leave the slots in the dairy facility (temporarily) vacant. This fact sheet discusses the factors that determine the maximum price a dairy producer can afford to pay now for dairy heifers when the dairy facility is not operating at full capacity. The approach outlined in this fact sheet is not directly appropriate for making decisions about replacing a cow with a heifer. However, the approach is appropriate when dairy facilities have expanded but are still vacant. Tax implications are ignored and not discussed.

The decision to purchase a heifer is an investment decision. As with any investment decision, a basic rule is that the investment is worthwhile if the expected net present value of the investment is greater than $\$ 0$ (assuming people are risk neutral). The net present value is the sum of all cash flows (receipts and expenses) that are affected by the decision to purchase the heifer, measured in today's dollars. The idea is that a dollar received or spent in the future is worth less than a dollar received or spent today. The present value (PV) of a future cash flow (FV) that is received or spent $\mathrm{n}$ periods in the future depends on the interest rate ( $r$ ) as follows: $\mathrm{PV}=\mathrm{FV} *(1 /(1+\mathrm{r}))^{\mathrm{n}}$. For example, the present value of $\$ 100$ feed expenses 24 months from today, at $8 \%$ annual interest and compounded monthly, is $\$ 100$ $*(1 /(1+0.08 / 12))^{24}=\$ 85.26$.

To estimate cash flows, only receipts and expenses that will change because the heifer is purchased or not need to be taken into account. These are called variable receipts and expenses.

Furthermore, the timing of the receipts and expenses must be estimated to calculate their PV.

It is not always easy to determine which expenses and receipts will change and by how much if a heifer is purchased. Expenses for the heifer purchase, feed, and breeding can be considered variable. Other expenses, such as for labor, may or may not change with the purchase of the heifer. If the labor costs don't change with the heifer purchase, then they should not be included in the net present value calculation. Expenses for cropping, milk marketing, and depreciation costs most likely will not change and are therefore considered fixed. They

1. This document is AN148, one of a series of the Department of Animal Sciences, Florida Cooperative Extension Service, UF/IFAS. Published March 2004. Please visit the EDIS Web Site at http://edis.ifas.ufl.edu

2. Albert de Vries, Asssistant Professor, Department of Animal Sciences, University of Florida; Russ Giesy, Multi-County Dairy Agent IV, Sumter County; Florida Cooperative Extension Service, Institute of Food and Agricultural Sciences, University of Florida, Gainesville, 32611.

The Institute of Food and Agricultural Sciences (IFAS) is an Equal Employment Opportunity - Affirmative Action Employer authorized to provide research, educational information and other services only to individuals and institutions that function without regard to race, creed, color, religion, age, disability, sex, sexual orientation, marital status, national origin, political opinions or affiliations. For information on obtaining other extension publications, contact your county Cooperative Extension Service office. Florida Cooperative Extension Service / Institute of Food and Agricultural Sciences / University of Florida / Larry R. Arrington, Interim Dean 
should not be included. Receipts for milk sales, calf sales and finally the cull value may be considered variable. The interest rate and a heifer's useful time in the herd must also be determined.

A straightforward calculation is to estimate the variable receipts (milk, calf sales) and expenses (feed, labor, other) per month and then subtract the heifer purchase price and add the cull receipt in the end. Table 1 provides an example. The receipts and revenues are based on the Dairy Business Analysis Project, which annually surveys the financial results of dairy farms in Florida and Georgia.

Table 1 shows that the PV of the cash flows associated with the heifer purchase (excluding the price for the heifer) is $\$ 2,209$. This means the maximum worth of the dairy heifer in the example is $\$ 2,209$. If the dairy heifer can be purchased for, say, $\$ 1,800$, then the net present value of the decision is $\$ 409$ and the investment is a good one. If the market price is higher than the maximum worth of a dairy heifer, the dairy producer is better off not to purchase the heifer and leave the dairy facility partially vacant.

Table 2 shows that changes of $10 \%$ in expenses and receipts affect the maximum worth of the heifer significantly.

If labor cost expenses are assumed to be fixed ( $\mathrm{F}$ $=\$ 0.00 / \mathrm{cwt}$ ), then the PV of the cash flow (the maximum worth of the heifer) is increased to $\$ 3,361$ (Table 3). This raises the maximum worth of the heifer by $\$ 1,152$ because the variable receipts minus expenses per year are increased from $\$ 851$ to $\$ 1361$. On the other hand, now that the labor expenses are fixed, the total fixed cost increase by $\$ 3.00 * 17,000 / 100=\$ 510$ per year. Tables 2 and 3 show how realistic differences in receipts and expenses and whether expenses are fixed or variable, can dramatically change the maximum worth of a heifer. Therefore, the maximum worth of a heifer varies from farm to farm. The dairy farmer has to determine what the estimated annual receipts and expenses are that are changed if the heifer is purchased. It is important to determine which expenses are fixed and which vary with the heifer purchase, as the examples with the labor expenses show. Only variable expenses need to be included.
A spreadsheet is available to calculate the maximum worth of a dairy heifer for different receipts and expenses. It is available free of charge at http://dairy.ifas.ufl.edu/spreadsheets/heifervalue.xls.

The examples in Tables 2 and 3 were calculated with this spreadsheet.

The maximum worth of a dairy heifer to a farm does not imply that the farm is profitable when a heifer can be purchased for less than that maximum. Because almost all receipts on a farm are variable, the total receipts just cover the variable expenses when heifer prices are near their maximum worth but no money is left to cover the fixed costs. Fixed costs that need to be covered, for example for depreciation and maintenance, are easily at least $\$ 400$ per cow per year. Fixed labor expenses need to be paid, too. Whenever the market price is just somewhat less than the maximum worth of the heifer to the farm, the purchase of expensive heifers merely reduces the financial losses of the farm. Of course continued losses are not sustainable in the long run and the dairy farm will be forced out of business. 
Table 1. Step-by-step calculation of the present value (PV) of the cash flow associated with a heifer purchase. The PV (cash flow) is the maximum worth of the dairy heifer. Spreadsheets such as Microsoft Excel contain built-in formulas to calculate the PV.

\begin{tabular}{|c|c|c|c|}
\hline A & Milk yield / year (lbs) & 17,000 & \\
\hline B & Milk price / cwt & $\$ \quad 16.00$ & \\
\hline C & Calf receipts ( 1 calf per 14 months) & $\$ 100$ & \\
\hline D & Variable receipts / year & $\$ 2,806$ & $=\mathrm{A} / 100 * \mathrm{~B}+\mathrm{C} * 12 / 14$ \\
\hline $\mathrm{E}$ & Feed expenses / cwt & $\$ \quad 7.00$ & \\
\hline $\mathrm{F}$ & Labor expenses / cwt & 3.00 & \\
\hline G & Other variable expenses / cwt & $\$ \quad 1.50$ & \\
\hline $\mathrm{H}$ & Variable expenses / year & $\$ 1,955$ & $=(E+F+G) / 100^{*} A$ \\
\hline । & Var. receipts minus expenses / year & $\$ 851$ & $=\mathrm{D}-\mathrm{H}$ \\
\hline J & Var. receipts minus expenses / month & $\$ 70.89$ & $=\mathrm{I} / 12$ \\
\hline $\mathrm{K}$ & Interest / month ( $8 \%$ annual interest) & $0.67 \%$ & $=8 \% / 12$ \\
\hline $\mathrm{L}$ & Time in herd (months) & 30 & \\
\hline M & PV(var. receipts minus expenses) & $\$ 1,922$ & $=P V(K, L,-J, 0)$ \\
\hline$N$ & Cow cull receipt & $\$ 300$ & \\
\hline O & PV(cull receipt) & $\$ 287$ & $=P V(K, L, 0,-N)$ \\
\hline $\mathrm{P}$ & $\mathrm{PV}$ (cash flow) & $\$ 2,209$ & $=\mathrm{M}+\mathrm{O}$ \\
\hline
\end{tabular}

Table 2. Sensitivity analysis of the maximum worth of the heifer to changes in receipts and expenses, compared to Table 1. Labor expenses are assumed variable at $\$ 3 / \mathrm{cwt}$.

\begin{tabular}{cccc}
\hline & \multicolumn{3}{c}{ Receipts } \\
\cline { 2 - 4 } Expenses & $-10 \%$ & $0 \%$ & $10 \%$ \\
\hline$-10 \%$ & $\$ 2,016$ & $\$ 2,650$ & $\$ 3,284$ \\
$0 \%$ & $\$ 1,575$ & $\$ 2,209$ & $\$ 2,842$ \\
$+10 \%$ & $\$ 1,133$ & $\$ 1,767$ & $\$ 2,401$ \\
\hline
\end{tabular}

Table 3. Sensitivity analysis of the maximum worth of the heifer to changes in receipts and expenses, compared to Table 1. Labor expenses are assumed variable at $\$ 3 / \mathrm{cwt}$.

\begin{tabular}{cccc}
\hline & \multicolumn{3}{c}{ Receipts } \\
\cline { 2 - 4 } Expenses & $-10 \%$ & $0 \%$ & $10 \%$ \\
\hline$-10 \%$ & $\$ 3,053$ & $\$ 3,687$ & $\$ 4,321$ \\
$0 \%$ & $\$ 2,727$ & $\$ 3,361$ & $\$ 3,995$ \\
$+10 \%$ & $\$ 2,400$ & $\$ 3,034$ & $\$ 3,668$ \\
\hline
\end{tabular}

